\title{
АРХЕОЛОГ В.С. ВОЛОШИН - НА ПУТИ К ИСТИНЕ
}

\section{(C) 2019 г. В.К. Мерц}

Известному казахстанскому археологу Валерию Степановичу Волошину исполнилось 70 лет. По современным меркам это ещё не старость, но далеко уже и не молодость, в науке это целый путь, а в случае с Валерием Степановичем, насколько могу судить по многолетней совместной работе и ещё более длительному общению, путь, безусловно, особенный, личный, если не сказать вообще уникальный. Источник в таких случаях обычно кроется в индивидуальности человека. Ещё в студенческие годы, например, принятая им стратегия археологической разведки на велосипеде принесла хорошие плоды - были выявлены десятки новых памятников каменного века, среди которых известные сейчас стоянки-мастерские палеолита Вишнёвка-3-6 и Туйемойнак, стоянки неолита Вишнёвка-1, Бокалы-Булак, Есинкабул-Булак, Кокчетау-1, Молодёжное и другие. А врождённая интуиция и активная работа с литературой помогли быстро разобраться с ситуацией: были выделены комплексы ашеля (Вишнёвка-3), среднего палеолита (Туйемойнак), специфическая бифасная группа (Вишнёвка-4-6) для разделения индустрий с открытых местонахождений использовался выработанный им метод учёта характера поверхностей артефактов по признакам эоловой корразии и химического выветривания.

Ключевые слова: археология, В.С. Волошин, Центральный Казахстан, каменный век, палеолит, комплекс, индустрия, индивидуальность человека

Моя первая встреча с Валерием Степановичем произошла в 1980 г. Помню как я, 17-тилетний паренёк, увлечённый археологией и уже успевший обегать в поисках древностей все окрестности Степногорска, к окончанию средней школы как-то заметался в надежде найти более организованное и достойное выражение для своих устремлений. Прибыв в Алма-Ату в Институт истории, археологии и этнографии им. Ч.Ч. Валиханова АН КазССР, я начал было говорить о своих находках и мечте, но известный археолог Анна Георгиевна Максимова, улыбаясь и всё понимая, посоветовала мне поехать в Целино- град, где при областном историкокраеведческом музее, как она сказала, ежегодно формируется летняя археологическая экспедиция и руководит всем археолог В.С. Волошин. По возвращению домой, не откладывая, я написал ему письмо и через какое-то время получил ответ - «Приезжай».

И вот в начале июня я был уже в Целиноградском областном историкокраеведческом музее, находившемся на пересечении улиц Карла Маркса и Октябрьской. Здесь в высоком и красивом здании - Доме купца Кубрина располагалась экспозиция музея и было довольно людно: одна группа экскурсантов сменялась другой. Ря- 
Мерц В.К. Археолог В.С. Волошин - на пути к истине

дом во флигеле находилась административная часть. Нельзя сказать, что здесь было много помещений, в комнате для научных сотрудников было явно тесно, стол археолога Волошина выделялся по нагромождению коробок с камнями. Валерий Степанович встретил меня приветливо, поинтересовался о моих успехах в археологическом поиске, предупредил о скором отъезде в поле. Затем повёл меня в довольно отдалённый район города - Старую слободу, в свой частный

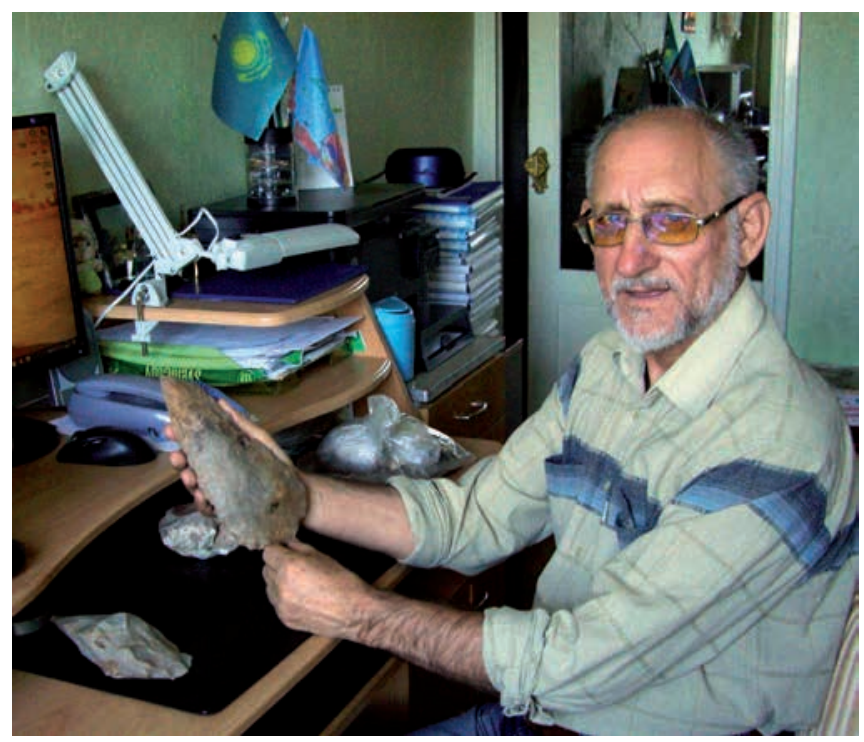

Рис. 1. Валерий Степанович Волошин. Фото из архива В.С. Волочина

Fig. 1. Valery S. Voloshin.

Photo from the V.S. Voloshin's archive дом, где я должен был жить в ожидании экспедиции. И не просто жить. Здесь находились ящики, наполненные довольно крупными желтоватыми камнями, сильно заглаженными и покрытыми лишайником - артефактами палеолита, как сказал он. В мои обязанности входило отмыть и очистить эти предметы от лишайника, к чему я сразу и приступил, с удивлением рассматривая совершенно непонятные мне гальки и обломки. На этом, однако, дело не закончилось после камней я ещё штопал экспедиционные палатки. Так состоялось моё знакомство с известным теперь археологом В.С. Волошиным - успешным исследователем палеолита Казахстана, которому он посвятил большую часть своей жизни, размышлений и трудов.

Валерию Степановичу пришлось совсем нелегко утверждать себя в археологии. Поступление на истфак Карагандинского пединститу- та в 1968 г. и двухлетнее общение с известным палинологом и специалистом по каменному веку, сотрудником Центрально-Казахстанского геологического управления М.Н. Клапчуком способствовали приобретению им только первого опыта в археологии. С отъездом последнего многое изменилось и В.С. Волошину пришлось рассчитывать только на самого себя.

После окончания института и прохождения военной службы Валерий Степанович в 1973 г. поступил на работу в Целиноградский областной историко-краеведческий музей и с этого времени уже целиком посвятил себя археологическим исследованиям. В 1974 г. им был получен Открытый лист и сформирована Целиноградская археологическая экспедиция. В этом же году экспедиция провела раскопки могильников бронзового века Балыкты и Звенигородка. В следующем 1975 г. при раскопках стоянки Жанбобек-4 впервые в чёт- 
ких стратиграфических условиях и в сопровождении богатой фауны крупных млекопитающих были получены материалы среднего и позднего неолита. В 1976-1977 гг. разведочными работами экспедиции был охвачен весь Тенгизский район, где помимо прочего были обнаружены крупные стоянки-мастерские палеолита АкКошкар-1, 6. В Балкашинском районе в долине речки Котунгуз был обнаружен стратифицированный пункт палеолита. Одновременно экспедицией проводились сборы археологического материала на памятниках Вишнёвка3-6 в верховьях Ишима и в Музбеле, Обалысане, Жаман-Айбате-4 в бассейне Сарысу. В 1978-1980 гг. экспедиция провела поквадратные сборы археологического материала в АкКошкаре-1: здесь помимо основного палеолитического комплекса с бифасами впервые был выделен более древний раннепалеолитический (ранний ашель?) комплекс.

На этот период приходится другая знаковая встреча Валерия Степановича - с Аланом Георгиевичем Медоевым, повлиявшая на него как на исследователя палеолита Казахстана. По рассказам самого Валерия Степановича, это был неординарный человек с широким мировоззрением, который произвел на него сильное впечатление. Его заинтересовала мысль А.Г. Медоева о существовании в Сарыарке пережиточных палеолитических индустрий, которая вполне отвечала его собственным размышлениям по поводу только что полученных материалов со стоянок Тенгизского района. Так возникла и была реализована идея существования в голоцене (или в финальном плейстоцене) архаичного Баршинского тейякского комплекса с ашельскими бифасами.
В 1981-1984 гг. Целиноградской археологической экспедицией была раскопана стоянка среднегопозднего неолита Вишнёвка-1, были проведены изыскания на новом и разрушавшемся могильнике бронзового века Ижевский-1 на берегу Вячеславского водохранилища, на стоянке неолита Бокалы-Булак-1 в междуречье Терсаккана и Кыпшак, на памятниках каменного века Ангренсор-1-2 возле одноимённого озера между Экибастузом и Майкаином.

Новый этап исследований начался в 1985 г. с раскопок открытого ещё М.Н. Клапчуком палеолитического памятника Батпак-7 на НураИшимском водоразделе. Общая площадь раскопа за три года работ

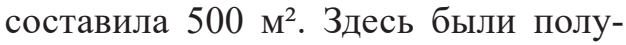
чены материалы среднего-позднего палеолита в сопровождении мамонтовой фауны. Одновременно в Батпаке были проведены геологостратиграфические исследования с использованием методов палеомагнетизма и спорово-пыльцевого анализа, результатом которых стало построение региональной четвертичной хроно-стратиграфической схемы в виде последовательности геологических формаций (свит): нижняя актасты (нижний эоплейстоцен) - верхняя актасты (верхний эоплейстоцен) - батпак (нижний-средний неоплейстоцен) - серия аллювиальных отложений речки Батпак (верхний плейстоцен). Работы завершились в 1988 г. открытием в отложениях формации нижняя актасты уникальной раннепалеолитической кварцевой индустрии - одной из древнейших человеческих индустрий в умеренном поясе Евразии, как полагает Валерий Степанович. Он предположил для этой индустрии возраст около 1,5 млн. 
лет, который противоречил принятым тогда схемам освоения человеком умеренного пояса Евразии. Однако находки эти, о которых он докладывал на Международных симпозиумах в Якутске (1989 г.), в Новосибирске (1990 г.) и Красноярске (1992 г.), по причинам их малой выразительности большей частью ведущих специалистов СССР по палеолиту не были признаны в качестве артефактов. А в Казахстане, при популяризации древнейшей истории, вопреки всему геолого-стратиграфическому контексту в Батпаке, они неожиданно оказались омоложенными до 800 тыс. лет - очевидно, в целях согласования с древнейшими тогда бесспорными артефактами стоянок Карама в Горном Алтае и Кульдара в Таджикистане, имевшими аналогичный возраст. Как известно, недавние открытия раннего палеолита в Грузии, Приазовье и Дагестане окончательно покончили со старыми схемами освоения человеком умеренного пояса Евразии и сделали возможным, как и предвидел Валерий Степанович, приблизить это весьма неординарное событие древности к рубежу в 2 млн. лет.

В 1988-1991 гг. экспедицией В.С. Волошина были проведены работы на палеолитических памятниках Батпак-18 и Мизар, относящихся к верхнему плейстоцену, а также на стоянках-мастерских каменного века на залежах эоценовых кварцитов в Старом Экибастузе. Одновременно была проведена разведка памятников каменного века в районе к северовостоку от Майкаина: здесь, среди несколько десятков обнаруженных памятников, были открыты пункты палеолита (Дузеке-1-3, Курома-14-15), стратифицированные стоянки мезолита (Талдыозек-21, Тарыап-1) и нео- лита (Курома-6, 12, 12a; Талдыозек-1). В это же время были проведены раскопки в Ангренсоре-2, где удалось зачистить две поверхности обитания финального палеолита или раннего мезолита. Другими интересными объектами исследования стали стоянки неолита Ак-Барак на р. Оленты (раскопки 1990 г.), Буревестник-2-3 на Левобережье Ишима (раскопки 1992-1993 гг.), Аксу-6 и НурмагамбетКыстау-1 возле Степногорска (раскопки 1995-1996 гг.), Кара-Тюбе в бассейне Атасу (раскопки 1997-1998 гг.). Новые открытые местонахождения каменного века были обнаружены в верховьях Ишима (Ижевский-6-7), на Левобережье Ишима (Каменка-3) и в бассейне Нуры (Улькен-Кундузды). В бассейне Сарысу были обнаружены и исследованы новые палеолитические памятники Азат-1, Казбек-1-2, Жуантобе и другие.

В долине Селеты в 2003 г. экспедицией был обнаружен и в 2007-2008 гг. исследован небольшой палеолитический пункт Бестогай, давший коллекцию грубых кварцевых артефактов, залегавших в верхнеплейстоценовом аллювии речки. Тогда же в бассейне Селеты были обнаружены и обследованы небольшие пункты палеолита Акжар, Кеноткель, Кызылту-1-2, Гнедина Балка, а также памятники неолита Шолаксор и Кызылагаш-3, 5.

Таков далеко не полный перечень археологических открытий и полевых исследований Валерия Степановича Волошина на территории Сарыарки. Как видим, он обширен количественно и тематически очень широк - от раннего палеолита до эпохи бронзы! Нужно иметь ввиду, что средств для выполнения каких-либо научных программ от государства он, 
за редким исключением, не получал; обычно облмузей ежегодно выделял ему небольшую сумму для организации школьного археологического лагеря, пока его не перевели в г. Кокчетав, - и это всё. Иногда удавалось получить небольшие средства от редких спонсоров, а в основном работа велась на энтузиазме.

Меня не раз интересовал вопрос, как это он, имея такие научные открытия и постоянные рабочие контакты с археологами Алматы, Караганды, Петропавловска, Москвы, Ленинграда, Новосибирска и Таджикистана (он четыре года работал осенью в экспедиции по изучению лёссового палеолита Припамирья, будучи соискателем у В.А. Ранова!), так и не стал частью одной из этих школ и умудрился остаться одиночкой, так и не защитил диссертацию. На все мои вопросы он обычно шутливо отвечал: «Вот так уберёгся...» или «Бог миловал...». Но однажды расшифровал свою позицию и это показалось мне интересным: «Видишь ли, - сказал он, - встречи с М.Н. Клапчуком, А.Г. Медоевым, а также и В.А. Рановым - это лишь небольшие штрихи в моей жизни. С первыми двумя, как и со мной, не связано никакой школы; у последнего была школа А.П. Окладникова, но сам он, кажется, не оставил своей школы, и это нормально. Не всё так однозначно. Я, наверное, с удовольствием объединился бы с какой-нибудь группой и даже слился бы в экстазе коллективного поиска, но каждый раз, когда что-то такое наклёвывалось, непонятная сила, как мне кажется, тут же начинала противодействовать и всё рассыпалось. Так же и с диссертацией. Человек это не чистый лист и, хотим мы этого или нет, но, обычно, там уже что-то написано, что и делает из него некоторый образ, с которым, скорее всего, высшие силы играют в разные игры. Один мой приятель, недавно ушедший от нас, был до мозга костей материалистом, уважал генетику и всё такое, страстно искал своё родство как можно глубже в истории. Он рассказал мне свою историю. Однажды вечером он, наконец, докопался до корней рода своего - до князя Василько Рюриковича из Волыни или Тьмутаракани. Лёг спать, утром проснулся от звонка в дверь, перед ним стояла женщина, которая спросила: „Василько здесь живёт?“ У него челюсть разом и отпала. Есть знаки на пути, и они подаются или через человеказомби - посланца от нижних планов бытия, как в случае с этим парнем, или как-то иначе с более высоких планов, и они как-бы указывают состояние и преимущественное предназначение человека. Вспомним Фому Аквинского, гордого по завершению своей „Суммы теологии“: однажды ему предстала картина, в одночасье показавшая всю ничтожность его творения или, например, Вифлиемскую звезду. Так вот школа, это когда образы-люди группируются в основном для научного (рационального) производства (есть, конечно, здесь и более тонкая струя), формулирования методологий, доктрин, масштабных проектов и т.п. Для удержания равновесия-симметрии на началах дополнительности ей должны быть противопоставлены отдельные представители науки, также производители, но всё же их главной задачей должно быть проведение в сфере науки с виду незаметной и более тонкой нити, ведущей от рациональности и к истине». «Подождите, - прервал я его, - что же такое истина, если вы 
противопоставляете её науке?» «Не науке, а рацио, и не я противопоставляю, а это уже заложено в самом бытие» - ответил он. «Иррациональное, ведущее, в конечном счёте, к субьектобьектному тождеству, очень стеснено в рамках организованной группы, его удел - отдельные индивидуумы, которых чем больше, тем естественно лучше для истины. Всё это напоминает известный даосский символ - круг, разделённый пополам дугой, в каждой из половинок которого находится ядро от противоположной половинки. Истина же - это, конечно, не наша известная „научная истина“, а то, что просто назвать ,так как всё есть“, т.е. истинность есть таковость бытия, когда вмешательство ума уже не требуется. Тогда мысли могут появляться, либо для того, чтобы разрушить это состояние таковости, если оно непрочно, либо же чтобы поиграть своими энергиями и затем опять уйти. Это, впрочем, и есть то, что все мы постоянно и делаем на поле археологии: поскольку божественный дом - это „основное пространство“ неразрушимо, то нам остаётся просто играть и уходить. Мы пребываем, насколько позволяет видеть наша проницательность, в закрытой системе. Поэтому все эти разговоры об эволюционном прогрессе, эпигенезе, антропогенезе... - всё это, возможно, не что иное, как нами хорошо организованное заблуждение». Таковы его убеждения относительно сушествующего порядка вещей.
Из всех материалов исследований на сегодняшний день, как я теперь понимаю, Валерием Степановичем играючи изучена и опубликована только небольшая часть - бо́льшая часть ещё только ждёт от него публикации.

Особенно интересными мне представляются его изыскания по раннему палеолиту. Первые исследователи палеолита Сарыарки А.Г. Медоев и М.Н. Клапчук при оценке геологического возраста последнего писали о среднем и верхнем плейстоцене (М.Н. Клапчук допускал возможность отнесения галечных орудий Обалысана к концу нижнего плейстоцена, т.е. по современной терминоло-

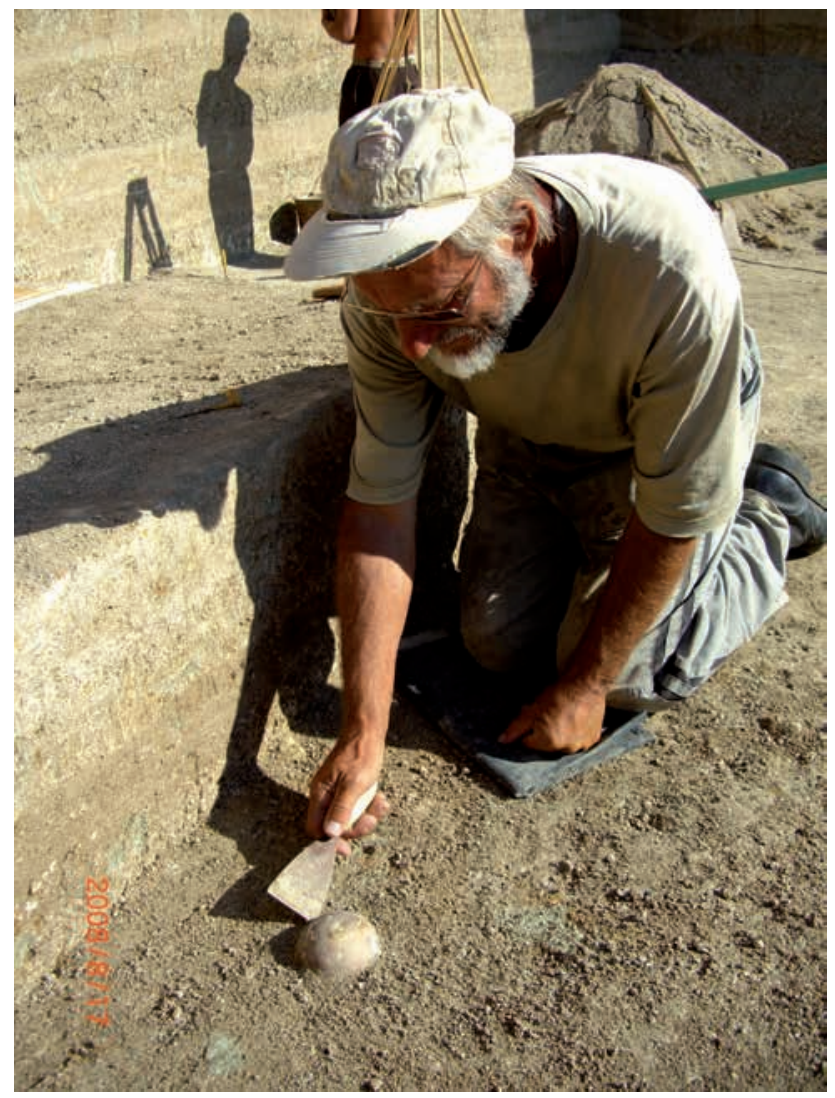

Рис. 2. В.С. Волошин. Стоянка Каменка, 1998 г. Fig. 2. V.S. Voloshin. Kamenka, 1998 
гии - к концу нижнего неоплейстоцена). Валерий Степанович, изучив галечный инвентарь Обалысана, Музбеля, Жуантобе и других памятников в бассейне Сарысу, начал выделять здесь хронологические серии, из которых сильно коррадированные образцы древнейших серий отнёс к эоплейстоцену-нижнему неоплейстоцену, образцы средней степени корразии - к среднему неоплейстоцену, а последующие серии - к верхнему плейстоцену. Конечно, в отсутствии стратиграфических данных это является его интуитивным решением. Но кто знает, может быть в этом случае, как и в случае с раскопками кварцевой индустрии в Батпаке, его интуиция просто опережает события! Насколько мне известно, от кварцевой индустрии Актасты, несмотря на всебщий скептис, он до сих пор не отказался. Более того, принимая во внимание уже отмеченные нами недавние открытия древнейшего палеолита на территории бывшего СССР, а также отрицательную намагниченность обеих актастинских формаций и характер ископаемых почв актастинского педокомплекса, он сейчас считает возможным углубить возраст этой индустрии приблизительно до 2 млн. л. н., т.е. по сути считает памятник древнейшим в Центральной Азии. Другой раннепалеолитический комплекс (древняя серия Ак-Кошкара-1), лишённый техники леваллуа и бифасов чёткой формы, но с крупными остроконечными орудиями, он также склонен относить к эоплейстоцену, скорее к верхнему, чем к нижнему. Ещё один раннепалеолитический памятник - УлькенКундузды, также лишённый геологостратиграфического контекста, отнесён им предположительно к нижнему неоплейстоцену. В картине, нари- сованной Валерием Степановичем, ранний палеолит Сарыарки венчается индустрией развитого (позднего) ашеля с выразительными бифасами и техникой леваллуа (древние серии Вишнёвки-3-4, Койтас-4, ЖаманАйбат-4) и возрастом предположительно среднего неоплейстоцена. Таким образом, по сравнению со схемами М.Н. Клапчука и А.Г. Медова, ранний палеолит Сарыарки в изображении В.С. Волошина предстаёт значительно богаче, древнее и более дифференцированным. Будем надеяться, что это не последний синтез автора.

Что касается изучения В.С. Волошиным среднего палеолита, то здесь для него решающее значение имеют памятники Батпак-7 и 18, а также Мизар-1-2, имеющие геолого-стратиграфический контекст и фауну крупных млекопитающих. В Батпаке-7 при раскопках автором незначительный материал залегал в переотложенном состоянии в линзах ритмопачек балочного аллювия, предположительно средневюрмского. В Батпаке-18 более массовый каменный инвентарь, найденный на поверхности, при зачистках автору удалось привязать к поверхности ископаемой почвы на глубине около 3 м; из почвы были получены споровопыльцевые спектры, близкие к ландшафтам лесостепи с присутствием вяза, а также радиоуглеродные даты по гумусу. Они указывают на весьма ранний в пределах среднего вюрма возраст этой почвы, а также индустрии, т.е. в пределах 50-40 тыс. л. н. В Мизаре-1-2 условия залегания среднепалеолитических артефактов ненамного отличались от Батпака-7. Ещё в двух памятниках - Котунгузе и Бестогае - немногочисленный и бо- 
лее архаичный каменный инвентарь (грубое сырьё) был извлечён при раскопках из основания палевой толщи верхнего плейстоцена (Котунгуз) и аллювиального песка палевой толщи, соответствующей верхнеплейстоценовой второй надпойменной террасе Ишима (Бестогай). Эти материалы, как считает автор исследований, скорее всего, древнее батпакских и должны относиться к последнему межледниковью-раннему вюрму. Остальные материалы по среднему палеолиту происходят из открытых местонахождений и интерпретация их затруднена: в своих публикациях Валерий Степанович отмечает некоторые различия между средним палеолитом Туйемойнака в бассейне Сaрысу и посташельскими комплексами с обилием двухсторонних орудий в Вишнёвке-3-6.

Верхний палеолит меньше всего представлен в собраниях В.С. Волошина. Это, прежде всего, выразительная индустрия из яшмо-кварцита с жилых поверхностей Ангренсора-2, представленная клиновидными и черепаховидными нуклеусами, пластинами, скрёблами, скребками и без бифасов. Возраст её до сих пор не удаётся уточнить - автором предполагается достаточно широкий интервал: финальный плейстоцен-начало голоцена. Ещё одним интересным памятником является Экибастуз-4, материалы которого с полевых работ 19881991 гг. в последнее время изучаются Валерием Степановичем. Памятник этот двухслойный. Нижний горизонт (под толщей маломощной карбонатизированной супеси, разбитой несколькими генерациями криогенных клиньев) относится им, предположительно, ко времени верхнего палеолита, хотя представленная здесь кварци- товая индустрия - отщепная, с нуклеусами среднепалеолитического облика, без бифасов - не содержит форм типично верхнепалеолитических и выглядит более архаично. Верхний (основной) горизонт включён в голоценовую почву: инвентарь содержит множество макроформ отщепов и нуклеусов, включая черепаховидные и клиновидные формы, есть бифасы и пластины, но доминируют достаточно архаичные отщепные орудия и широко представлена техника рассечения заготовок. К верхнему горизонту Валерий Степанович относится осторожно, допуская смешение здесь материала разного возраста и культур, а индустрию нижнего горизонта всё больше склоняется рассматривать как своеобразный архаичный пережиточный комплекс эпохи верхнего палеолита, что-то подобное Баршинскому комплексу Тенгизской степи. Кстати, феномен архаичных пережиточных индустрий каменного века Сарыарки ранее был прослежен им и на одном из памятников в урочище Талдыозек (район г. Майкаин), где кремнёвая индустрия, включённая в современную почву, демонстрирует, как считает Валерий Степанович, все основные характерные черты тейякского раннепалеолитического комплекса.

Мы намеренно здесь ограничились изложением изысканий нашего юбиляра только в области палеолита, полагая, что именно здесь они уже приобрели форму системы. За 50 лет творческого поиска Валерием Степановичем был внесен, как видим, немалый вклад в археологическую науку Казахстана, безусловно, еще не до конца понятый и оцененный.

В завершении хочется поздравить Валерия Степановича с юбилеем и пожелать ему творческого вдохно- 
вения и успехов в изучении собранных им коллекций по каменному веку Сарыарки, а также крепкого здоровья как необходимого условия исполнения всех его творческих замыслов.

\section{Список основных публикаций В.С. Волошина}

Местонахождение каменного века Баршин 3 в Тенгизской степи // Вопросы археологии и этнографии Центрального Казахстана. Караганда: КарГУ, 1982. С. 42-57.

Ашельские бифасы из местонахождения Вишневка 3 (Центральный Казахстан) // CA. 1984. № 4. С. 199-203.

Вопросы хронологии и периодизации палеолита Центрального Казахстана // Вопросы периодизации археологических памятников Центрального и Северного Казахстана. Караганда: КарГУ, 1987. С. 8-10.

Мустьерская индустрия из Кошкургана // Вопросы археологии Центрального и Северного Казахстана: сб. научн. трудов. Караганда: КарГУ, 1989. С. 3-12.

К типолого-стратиграфической схеме по палеолиту Центрального Казахстана // Маргулановские чтения: сб. матер. конф. Алма-Ата, 1989. С. 70-74.

Об истоках палеолита Центрального Казахстана // Маргулановские чтения1990: сб. матер. конф. М., 1992. Ч. 1. С. 49-53.

Стратиграфия и периодизация палеолита Центрального Казахстана // Хроностратиграфия палеолита Северной, Центральной и Восточной Азии и Америки: докл. Междунар. симпозиума. Новосибирск: «Наука», 1990. С. 99-106.

Основные этапы освоения палеолитическим человеком Казахского мелкосопочника // Палеоэкология и расселение древнего человека Северной Азии и Америки: тез. докл. Междунар. симпозиума. Красноярск, 1992. С. 39-43.

Исследования в Батпаке (Центральный Казахстан) // Обозрение результатов полевых и лабораторных исследований археологов, этнографов и антропологов Сибири и Дальнего Востока в 1993 г. Новосибирск: ИАЭт СО РАН, 1995. С. 263-267.

Памятник каменного века Талдыозек 21 // Сохранение и изучение культурного наследия Алтайского края: матер. научн.-практ. конф. Барнаул: изд-во Алт. ун-та, 1998. Вып. IX. С. 47-50.

Новые палеолитические памятники в бассейне Сарысу // Каменный век Казахстана и сопредельных территорий. Туркестан, 1998. С.70-82.

Древнепалеолитическое местонахождение Улькен-Кундузды // Каменный век Казахстана и сопредельных территорий: матер. междунар. конф., посвящ. 70-летию Х.А. Алпысбаева. Туркестан: Мирас, 1998. С. 83-91.

К изучению бифасных наконечников копий каменного века // Вопросы истории, археологии и этнографии Павлодарского Прииртышья: сб. научн. ст. Павлодар: ЭКО, 2000. С. 57-62.

Проблема первоначального освоения человеком Сары-Арки // 10 лет независимости Казахстана: итоги и перспективы развития: матер. Междунар. научн. конф. Алматы, 2001. С. 50-55.

К вопросу об истории изучения палеолита Сары-Арки // Изучение памятников археологии Павлодарского Прииртышья: сб. научн. ст. Павлодар: ЭКО, 2002. C. $21-43$.

Коллекция раннепалеолитических находок из Койтаса (Левобережное Прииртышье) // Изучение памятников археологии Павлодарского Прииртышья: сб. научн. ст. Павлодар: ЭКО, 2002. С. 64-74.

Проблема первоначального освоения человеком Сары Арки // Степная цивилизация Восточной Евразии. Т. 1. Древние эпохи. Астана: Култегин, 2003. С. 28-32. 
Новый палеолитический памятник Батпак-18 в Центральном Казахстане // Степная цивилизация Восточной Евразии. Т. 1. Древние эпохи. Астана: Култегин, 2003. C. 33-38.

Неолитическая стоянка Азат-3 в бассейне Сарысу // Новые исследования по археологии Казахстана: труды научн.-практич. конф. «Маргулановские чтения». Алматы, 2004. С. 220-225

Ранненеолитический комплекс Курома-12А // Изучение памятников археологии Павлодарского Прииртышья: сб. научн. ст. Павлодар: ЭКО, 2006. С. 24-38.

Новые памятники палеолита с галечным инвентарём в бассейне Сарысу // Археология Казахстана в эпоху независимости: итоги и перспективы: матер. научн. конф., посвящ. 20-летию независимости Республики Казахстан. Алматы: Институт археологии им. А.Х. Маргулана, 2011. Т. 1. С. 157-163.

Литические серии в инвентаре стоянки Аксу-6 // Маргулановские чтения-2011: матер. междунар. конф. Астана: ЕНУ им. Л.Н. Гумилева, 2011. С. 223-226.

Палеолитическая стоянка-мастерская Дузоке-3 // Вопросы археологии Казахстана. Алматы: НИЦИА «Бегазы-Тасмола», 2011. Вып. 3. С. 199-211.

Материалы по палеолиту северной части Сарыарки // Древний Тургай и Великая Степь: часть и целое: сб. научн. ст., посвящ. 70-летию В.Н. Логвина. КостанайАлматы: Институт археологии им. А.Х. Маргулана, 2015. С. 224-238.

М.Н. Клапчук - первый профессиональный археолог Караганды // Археологическое наследие Центрального Казахстана: изучение и сохранение: сб. научн. ст., посвящ. 70-летию организации ЦКАЭ Академии наук Казахстана. Алматы: НИЦИА «Бегазы-Тасмола», 2017. Т. 1. С. 130-136.

Стоянка-мастерская каменного века Ижевская-6 // Археологическое наследие Центрального Казахстана: изучение и сохранение: сб. научн. ст., посвящ. 70-летию организации ЦКАЭ Академии наук Казахстана. Алматы: НИЦИА «Бегазы-Тасмола», 2017. T. 2. C. $96-102$.

\section{Сведения об авторе:}

Мерц Виктор Карлович - кандидат исторических наук, директор, Центр археологических исследований им. А.Х. Маргулана, Павлодарский государственный университет им. С. Торайгырова (Павлодар, Казахстан); v_merz@mail.ru

\section{АРХЕОЛОГ В.С. ВОЛОШИН - АҚИҚАТҚА АПАРАР ЖОЛДА}

\section{В.К. Мерц}

Танымал қазақстандық археолог Валерий Степанович Волошин 70 жасқа толды. Қазіргі өлшем бойынша бұл қарттық жасқа жеткендік емес, бірақ сонау жеген жас та емес, ал ғылымда бұл дегенің бүкіл жүріп өткен жолың болғандықтан, оны өзім ұзақ жылдардан бері жақсы білетін және жақын араласатын Валерий Степановичтің өмір жолымен салыстыра бағалағанда, бұл жол, сөз жоқ дара, өзгеше, тіптен бірегей ерекше деп айтуға болады. Бұның астары жеке тұлғаның даралығында жатыр. Студенттік жылдардың өзінде велосипедпен археологиялық барлау жасау стратегиясын қабылдауының өзі тәп-тәуір жемісін берді - тас ғасырының он шақты ескерткіштері анықталды, олардың ішінде қазіргі белгілі Вишневка-3-6 және Түйемойнақ секілді палеолиттің тұрақ-шеберханалары, Вишневка-1, Боқалы-Бұлақ, Есенқабыл-Бұлақ, Көкшетау-1, Молодежное және т.б. неолит тұрақтары бар. Туа біткен ішкі түйсік пен әдебиеттпен белсенді жұмыс істеуі ахуалды тез болжауына көмектесіп отырды: ашелдер кешені (Вишнёвка-3), орта палеолит (Түйемойнақ), өзіндік ерекшелігі бар бифастық топ (Вишнёвка-4-6) - индустрияны ашық орналасқан орындардан 
бөлу үшін оның өзі жасаған артефактілердің үстіңгі сипатын эолдық корразия мен химиялық үгілу белгілері бойынша есепке алу әдісі қолданылды.

Түйін сөздер: археология, В.С. Волошин, Орталық Қазақстан, тас ғасыры, палеолит, тұлғаның даралығы

\section{ARCHAEOLOGIST V.S. VOLOSHIN - ON THE WAY TO THE TRUTH}

\section{V.K. Merz}

A famous Kazakhstan archaeologist Valery S. Voloshin is 70 years old now. Compared to present standards it is not old age yet, but nor youth. Concerning science there is already a whole path overpassed, and in a case with Valery S., as far as I can judge on a long-term collaboration and longer communication, his path is certainly exceptional, personal or even unique. The source in such cases is usually hidden in the identity of the person. In student's years, for example, the strategy of archaeological investigation by bicycle accepted by him gave a very good result - tens of new sites of the Stone Age including settlement-workshop sites of the Paleolith of Vishnyovka-3-6 and Tuyemoynak, sites of the Neolithic of Vishnyovka-1, Bokaly-Bulak, Esinkabul-Bulak, Kokchetau-1, Molodyozhnoe and others were revealed. Congenial intuition and proactive work with literature helped to deal with the situation quickly: there were allocated complexes of Acheul (Vishnyovka-3), the Middle Paleolithic (Tuyemoynak), specific chipper group (Vishnyovka-4-6) - he used the method of how to register the artifacts` surface nature basing on signs of Aeolian corrosion and chemical aeration to divide the industries from open deposits.

Keywords: archaeology, V.S. Voloshin, Central Kazakhstan, Stone Age, Paleolithic, identity of the person

\section{About the Author:}

Merz Viktor K. Candidate of Historical Sciences, Director, A.Kh. Margulan Center of Archaeological Research, S. Toraigyrov Pavlodar State University, Pavlodar, Kazakhstan; v_merz@mail.ru 